この中心指向器の方がよいであろ3.(1952. 10. 30)

\title{
写直 説 明
}

1. 泌康器科レントグンテーブルの管球（島津報国号にとりつけた空冷式 $10 \mathrm{KW}$ ) の先にとりつけた姏。管球に

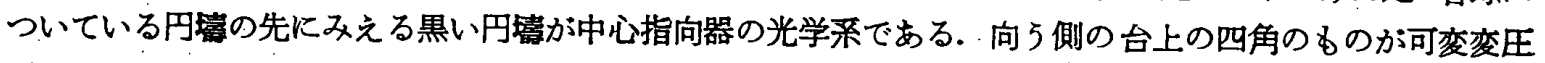
器である.

2. 管球の先にとりつけた処の近接写真. すぐそばにスイッチがみえる.

3. 中心がきつた後に中心指向器をわきにとりつけよ5としている処。下にみえるのは変圧器である.

4. レントゲン写真撮影中の中心指向器の位置. バネではねあげて固定してある.

5. 中心指向器からでた光か平面ブッキーの中央に焦点を結んでいる処。

6. 本器を用いて患者の蟀高上 1 横指に中心（光線で円く白くみえる）を定めた姏.

\section{常 識 講 座}

【問】最恵国待遇とは何でしようか。

【答】この間調印された日米友好通商航海条約には, 最惠国待遇といら言葉が度々出てくる．最る惠まれた 国であるといら待遇を通商条約に於て与えることで， 通商上の差別待遇を防止することを目的とする. 即ち 一国が他国と通商条約を結ぶ時に，その国が既に第三 国に対して与えている利益と権利は相手国にも及ぶと いらことである. 例えば A 国と B 国の通商条約に於 て，A 国か：国に対して既に低廉な関税率を協定して あるとすれば, $\mathrm{A}$ 国はC 国と同様 B 国にす低廉な関税 率の利益を与える.こんどの日米通商条約は特に相互 主義最惠国待遇といつて，ある業種に限り，米国も日 本に同様の利益を与えなければ，適用されないという 制限を設けてある.

【問】日本の政党の大要を御説明下さい。

【答】自由党，現在は吉田派と鵎山派に分れたか，外 国の新聞ではウルトラ・コンサーバチヴ（超保守党） といわれる. インテリ，労働者に評判がわるいが，封 建的な意識の持主の支持を兄ている.

改進党 自由党と社会党の中間にあり、いわゆる修 正資本主義を標榜しているが，本質的には自由党と同 じ基盤に立つ保守政党である.

社会党 社会民主主義の党で, 自由党改進党に比し より進歩的といわれるか，反共の点では一致してい る. 右派と左派に分れ抗争が絶えない。

労費党 かつて社会党の左派に属していた人の一部 が，社会党の日和見的行動に反対して脱党し，労農党 を結成した，社会民主主義の党ではあるが，容共的で ある点で自由, 改進, 社会の各党と質的に区別される。

共座党 資本主義と鋭く対立するレーニン主義を奉 ずる政党で、革命手段によつてプロレタリフ独裁を達 成せんとする. マルクスの階級闘争理論は，資本主義
が高度に発達する結果, 必然的に崩壤して遂に労働者 階級が政権を獲得すると説くか，マルクス主義は社会 党の如く漱進的に経済共同体の社会化を方針とするる のと，共産党の如く急進的に革命によつて労働者階級 の独裁を企てるすのとの二派に分れる.

緑風会 参議員議員中の無所属議員を以て構成され たものであるが，自由党や改進党の党友としての立場 をとる人が多い，官嘹出身者や山本有三の如き文化人 議員を沢山含んでいるが，概して保守的な人が極めて 多い。

【問】政治献金と政治資金を説明して下さい。

【答】政治献金 金がなければ当選もせず政治すでき ないことは，今日の社会に於ける政治活動の常識であ. る. それは政治資金規正法とい5一片の法律によつて 是正し得るほど簡単なことではない，政治献金は資本 主義社会に於ける政治の遂行上展々行われる.大資本 家が政治家に多額の金銭を献納する.代りに政治家は 反対給付として，色々の利権便宜を大資本家に与え る.これによつて大資本家は, 献金の何倍何十倍の利 益を得るのが通常である.19世紀末のアメリカに括け る金権政治の弊害は有名であるが，わが国でも昭電事 件がその好例である.

政治资金 政治活勤に必要な資金のことで，政治資 金规正法(昭和二十三年七月二十九日法律第 194) k上 つて規定されている. 同法は政党，協会その他の団体 及び公職の候補者などの政治活動の公明を図り，選挙 の公正を確保し，以て民主政治の健全な発達に寄与す ることを目的として制定されたすので，これ等の団体 は所定の会計帳簿を設け，寄附その他の収入支出を明 確に記載し，報告を選挙管理委員会に提出せねばなら

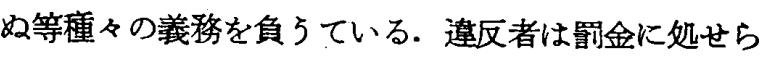
れるが，この法律のみによつて政治活動か㳂明に行わ れないことはいうまでもなく，政治資金にからむ政治 家官僚などの贈収賄事件が後を絶たない（S） 